NOTE

\title{
Determination of conversion factors for estimation of subantarctic marine bacterial production measured by ${ }^{3} \mathrm{H}$-thymidine incorporation methodology
}

\author{
D. Delille*, G. Cahet \\ Observatoire Océanologique de Banyuls, Université P. et M. Curie, U.R.A. 2071, Laboratoire Arago, F-66650 Banyuls sur mer, France
}

\begin{abstract}
In order to determine conversion factors for ${ }^{3} \mathrm{H}$ thymidine incorporation to bacterial growth rate, we performed a series of seawater culture experiments on surface mixed layer samples in a subantarctic coastal area. Four different treatments were used: bacterivory reduction (dilution or filtration), nutrient enrichment and temperature increase. Conversion factors were estimated by the 'integration approach' the increase in bacterial biomass (biomass at final time point minus initial value) was divided by incorporation rates integrated over time during the experiment. Both bacterial abundance and mean cell volumes markedly increased in all experiments. The manipulation effects were strongest in the high temperature batch compared with the other experiments. However, the 4 different treatments yielded comparable conversion factors ranging from $9.7 \times 10^{5}$ to $1.5 \times 10^{6}$ cells $\mathrm{pmol}^{-1}$ with a mean value of $1.2 \times 10^{6} \mathrm{cells} \mathrm{pmol}^{-1}$.
\end{abstract}

KEY WORDS: Bacterial production - Psychrophilic bacteria . Antarctica

The use of ${ }^{3} \mathrm{H}$-thymidine incorporation to derive an estimate of heterotrophic bacterial growth rate has been practiced extensively in aquatic microbial ecology (reviewed by Riemann \& Bell 1990). However, bacterioplankton can dissimilate and shunt exogenously supplied thymidine into various macromolecular fractions, rather than use it for DNA synthesis. The extrapolation of ${ }^{3} \mathrm{H}$-thymidine incorporation to bacterial growth rate requires several assumptions that apparently are not valid in all areas. Several papers have challenged the validity of ${ }^{3} \mathrm{H}$-thymidine assay assumptions. In particular, the extrapolation factor for the conversion of moles of ${ }^{3} \mathrm{H}$-thymidine incorporated to bacterial cells produced, which was assumed to be constant, is now known to vary under both laboratory

'E-mail: delille@arago.obs-banyuls.fr and field conditions (Kirchman et al. 1982, Bell et al. 1983, Scavia \& Laird 1987, Smits \& Riemann 1988, Børsheim 1990, Kirchman \& Ducklow 1993). Karl et al. 1991 found an empirically determined conversion factor ranging from 2 to $55 \times 10^{6}$ cells $\mathrm{pmol}^{-1}$ in the Bransfield Strait (Antarctica). Consequently, the use of a constant value in carbon budgets and models is problematic, and we are not yet able to present a simple solution to account for this variability.

The purpose of the present study is to compare conversion factors deduced from 4 different manipulations (minimizing grazing by dilution or filtration, nutrient addition and temperature increase). The influence of chemical extractions of bacterial material used to determine thymidine uptake rates was also pointed out as a complement.

Materials and methods. This study was conducted from January to April 1992 in the Kerguelen archipelago. In order to determine conversion factors, subsurface seawater was collected in Morbihan Bay (Stn Z; $49^{\circ} 21.5^{\prime} \mathrm{S}, 70^{\circ} 13.25^{\prime} \mathrm{E}$ ) using sterile glass bottles at $10 \mathrm{~cm}$ depth. Bacterial growth was followed in a number of seawater batch cultures (2 1 in 51 acid-washed sterile glass bottles). Five microcosms were treated as follows: (1) no treatment, (2) filtration through $3 \mu \mathrm{m}$ filters at $<200 \mathrm{~mm} \mathrm{Hg}$, (3) filtration through $0.2 \mu \mathrm{m}$ filters and inoculation with ambient seawater to give a 10 -fold dilution of the inoculum, (4) peptone addition, (5) high incubation temperature $\left(15^{\circ} \mathrm{C}\right.$ as compared to $7^{\circ} \mathrm{C}$ for the other batches). Except for Expt 5, the batch cultures were incubated in the dark close to in situ temperature (between 6 and $8^{\circ} \mathrm{C}$ ). With approximately $10 \mathrm{~h}$ intervals, $70 \mathrm{ml}$ subsamples were removed from the bottles for estimation of bacterial biomass and production.

Total bacteria were determined by acridine orange direct count (AODC) with an Olympus epifluorescence 
microscope according to the method of Hobbie et al. (1977). Biovolumes were estimated using an ocular micrometer. Viable counts of saprophytic bacteria were made using the spread plate technique on the $2216 \mathrm{E}$ medium (Oppenheimer \& ZoBell 1952). Inoculated plates were incubated for $15 \mathrm{~d}$ at $7^{\circ} \mathrm{C}$. The rate of uptake of tritiated thymidine was measured according to the procedure of Fuhrman \& Azam (1982). Samples were incubated for 1 and $2 \mathrm{~h}$ with $10 \mathrm{nM}{ }^{3} \mathrm{H}$-thymidine (final concentration) under in situ conditions. In order to discriminate the fate of assimilated thymidine, 3 different final treatments were used after 1 and $2 \mathrm{~h}$ in situ incubations and the addition of ice-cold $10 \%$ trichloroacetic acid (TCA). (1) Three ml subsamples were extracted in $0.25 \mathrm{~N} \mathrm{NaOH}$ (final concentration) and chilled on ice. These samples were stored on ice for up to $48 \mathrm{~h}$, then neutralized with ice-cold TCA (final concentration, $20 \%$ ) and filtered onto $22 \mathrm{~mm}$ diameter, $0.2 \mu \mathrm{m}$ membrane filters. Finally the samples were extracted in the filter holders by rinsing 3 times with $80 \%$ ethanol (Wicks \& Robarts 1987). (2) Three ml subsamples were filtered onto $22 \mathrm{~mm}$ diameter, $0.2 \mathrm{\mu m}$ membrane filters and then extracted by rinsing the filters over a vacuum 3 times with ice-cold $5 \%$ TCA and by rinsing 3 times with $80 \%$ ethanol as suggested by Wicks \& Robarts (1988). (3) Treatment was similar to that in (2) with a final rinsing with $1 \mathrm{ml}$ of hot $10 \%$ TCA.

Conversion factors (CF) were estimated by the integration approach'; the increase in bacterial biomass (biomass at final time point minus initial value) was divided by incorporation rates integrated over time during the experiment (Kirchman 1992). The rates were calculated according to an equation derived by
Kirchman et al. (1982): CF $=\left(\mu N_{0}\right)\left(v_{0}^{-1}\right)$ where $v_{0}$ was the initial thymidine incorporation rate. Growth rate constants were calculated from $\mu=T^{-1}\left(\ln N_{\mathrm{f}}-\ln N_{0}\right)$, where $N_{f}$ and $N_{0}$ were the final and initial total abundance and $T$ the duration of the experiment (Chrzanowski et al. 1993). Bacterial $C$ content was calculated according to the equation: Bacterial $\mathrm{C}=90 \times V^{0.6}$ where $V$ was the mean cell volume (Simon \& Azam 1989, Bååth 1994).

Results. There was no discernible increase of total bacterial numbers in the control experiment (Fig. 1). In contrast, cell numbers increased in all other microcosms. Both total and saprophytic bacterial abundance markedly increased in the absence of predators. The peptone addition stimulated bacterioplankton growth. However, saprophytic increase was larger than the total increase. High incubation temperature also induced a clear stimulation of bacterial growth but, in contrast with the other microcosms, a lag time was detectable (10 h for total abundance). The high temperature batch was the only experiment where CFU (colony forming units) showed a typical sigmoid growth pattern.

A decrease of mean cell volumes followed by an increase occurred during all experiments (Fig. 2).

As with bacterial abundance, short-term incorporation rates for thymidine increased during all our incubations experiments (Fig. 3). However, the manipulation effect was strongest in the high temperature batch compared with the other experiments. The 3 chemical extraction procedures gave very similar results. The lower values obtained with treatment 3 in the temperature experiment were the only noticeable point of difference.

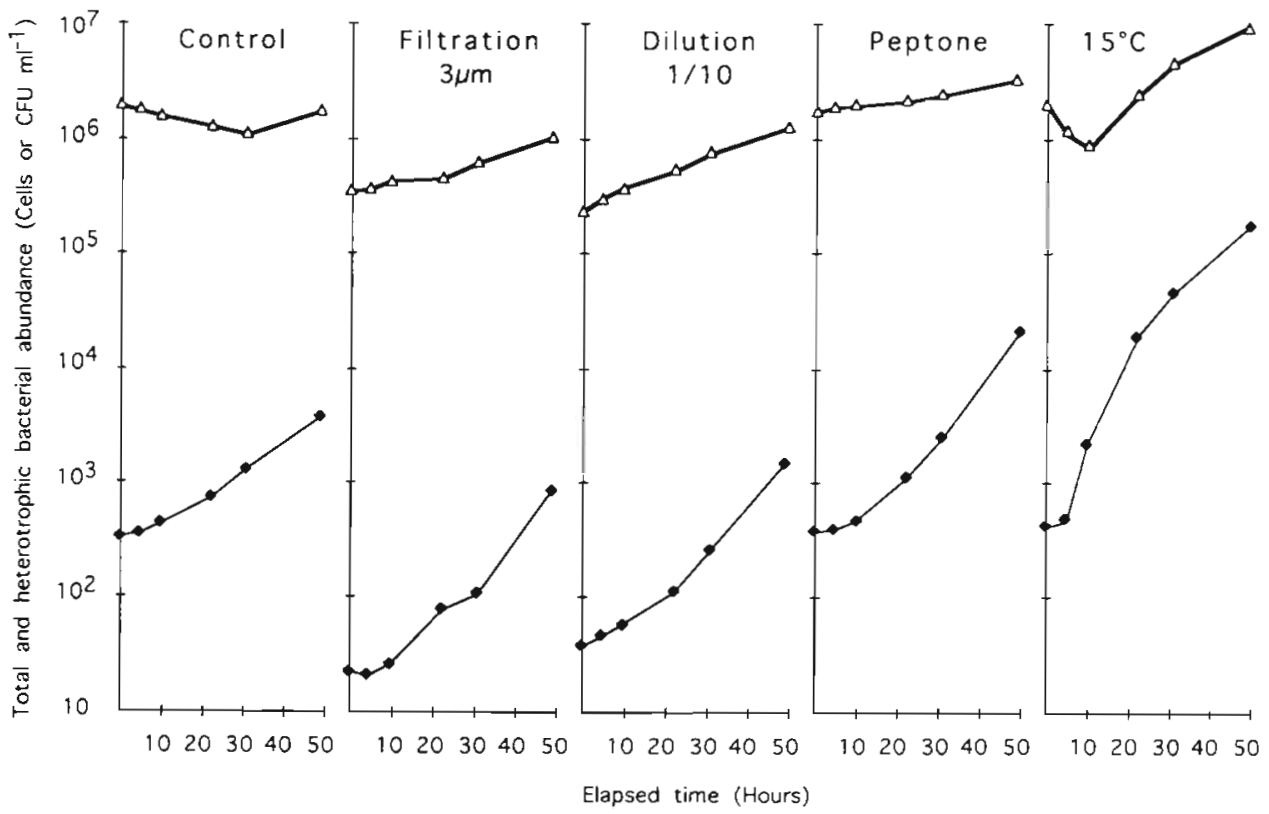

Fig. 1. Time course of total (thick line) and heterotrophic bacterial (thin line) abundance during microcosm expenments 
Fig. 2. Time course of total biovolume (thick line) and mean cell volume (thin line) during microcosm experiments

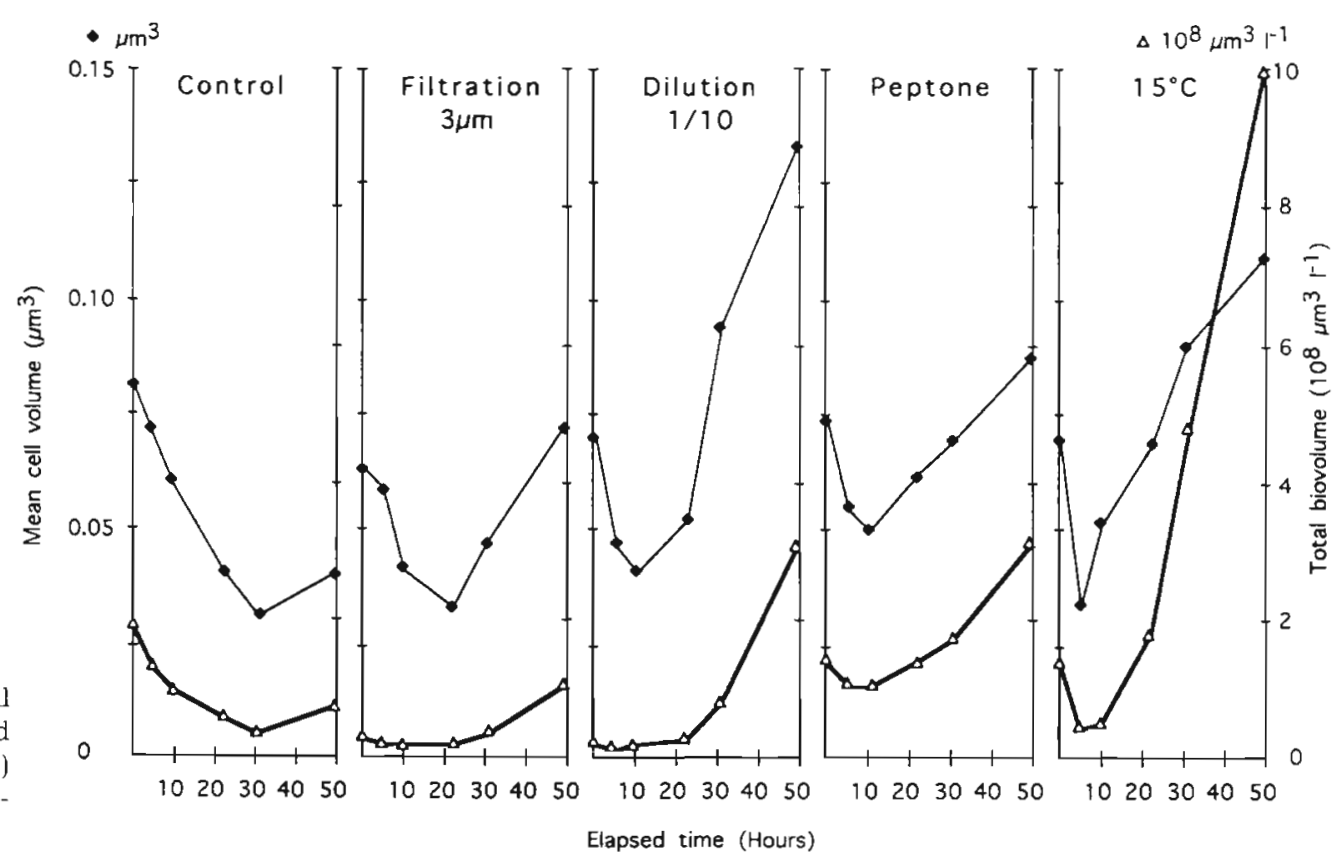

Calculated conversion factors are shown in Table 1. The 4 different treatments yielded comparable conversion factors ranging from $9.7 \times 10^{5}$ to $1.5 \times 10^{6}$ cells $\mathrm{pmol}^{-1}$ and from 15 to $30 \mathrm{ng} \mathrm{C} \mathrm{pmol}{ }^{-1}$.

Discussion. Because the rates and patterns of nutrient utilization can be highly variable, elucidating the factors regulating bacterial growth and its concomitant influence on elemental fluxes is central to understanding biogeochemical cycles in the marine environment (Ducklow 1994). Predation and mortality due to viruses can partly regulate bacterial standing stock
(Azam et al. 1983, Kuosa \& Kivi 1989, Bratbak et al. 1992, 1994, Shiah \& Ducklow 1995, Weinbauer \& Peduzzi 1995, Steward et al. 1996). A number of observations suggest that the microbial loop is also controlled by the interaction of 2 other main factors, temperature and substrate supply. These 2 factors clearly induced a strong stimulation of subantarctic bacterioplankton in our study. Based upon the analysis of 66 published studies, Rivkin et al. (1996) reported a weak relationship between specific growth rate of bacterioplankton and temperature with a $\mathrm{Q}_{10}=1.5$.
Fig. 3. Time course of thymidine incorporation (thick line: extraction treatment 1 , thin line: extraction treatment 2, dotted line: extraction treatment 3) during microcosm experiments

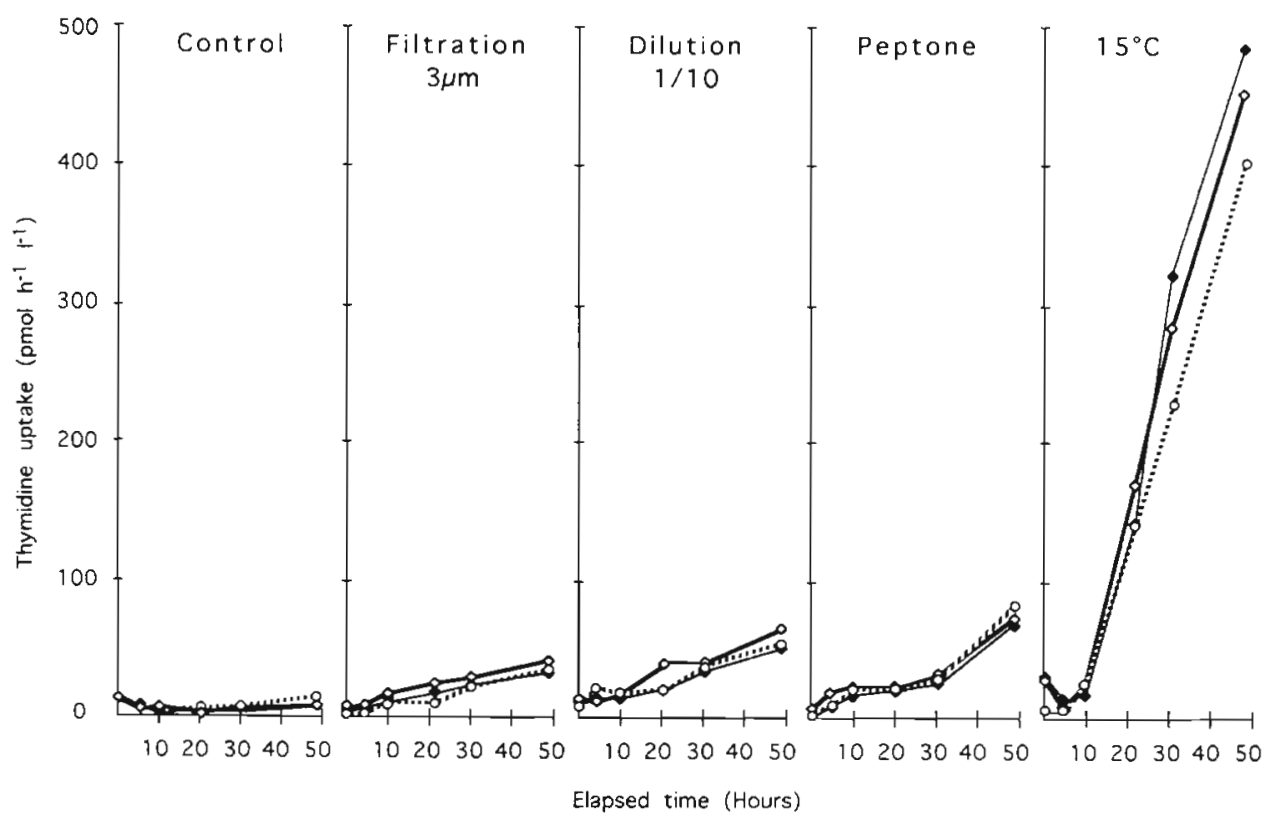


Table 1. Conversion factors deduced from microcosm experiments

\begin{tabular}{|lccc|}
\hline Method & $\begin{array}{c}\text { Extraction } \\
\text { procedure }\end{array}$ & $\begin{array}{c}\text { Conversion factors } \\
10^{6} \text { cells pmol }^{-1}\end{array}$ & ng C pmol \\
Filtration & 1 & 0.97 & 15 \\
& 2 & 0.98 & 15 \\
Dilution & 3 & 1.3 & 20 \\
& 1 & 1.2 & 26 \\
Peptone & 2 & 1.4 & 30 \\
& 1 & 1.3 & 28 \\
$15^{\circ} \mathrm{C}$ & 2 & 1.2 & 21 \\
& 3 & 1.4 & 23 \\
Mean & 1 & 1.2 & 20 \\
& 3 & 1.2 & 25 \\
& 3 & 1.3 & 25 \\
& & 1.5 & 23 \\
\hline
\end{tabular}

They also found that the specific growth rate of bacteria from cold $\left(<4^{\circ} \mathrm{C}\right)$ and warm $\left(>4^{\circ} \mathrm{C}\right)$ waters were not significantly different. In contrast, in this study a $10^{\circ} \mathrm{C}$ increase induced a more than 10 -fold increase in thymidine uptake. This positive influence of temperature is in agreement with numerous observations that reported significant correlations between bacterial production and temperature (Morita et al. 1977, Hanson \& Pope 1981, Delille et al. 1988, Hoch \& Kirchman 1993, Shiah \& Ducklow 1994). However, such large increases in temperature $\left(10^{\circ} \mathrm{C}\right)$ are rarely found under natural subantarctic conditions. In any case, these data confirm previous studies in the same area which demonstrated that a large majority of the subantarctic and antarctic heterotrophic bacterial isolates have substantial growth rates for a wide range of temperatures 10 to $20^{\circ} \mathrm{C}$ : Straka \& Stokes 1960 , Herbert \& Tanner 1977, McMeekin \& Franzmann 1988, Delille \& Perret 1989, Nedwell \& Rutter 1994, Helmke \& Weyland 1995). Over large scales the best predictors of bacterial biomass and productivity may be factors related to the total resource level in an ecosystem. In addition, bacterial resources are probably influenced by food-web interactions (Pace \& Cole 1994).

When bacterial growth is unbalanced, different estimating methods may yield different values for conversion factors because cell numbers, mean cell volumes and isotope incorporation change at different rates (Ducklow et al. 1992). The empirically determined thymidine conversion factors can vary $>500$ fold (Kirchman et al. 1982, Coveney \& Wetzel 1988, Smits \& Riemann 1988, Ducklow et al. 1992). Despite these observations the conversion factors derived from the 4 experimental methods are homogenous (Table 1 ). Furthermore, these factors agree well with the factor of $1.25 \times 10^{6}$ cells pmol $^{-1}$ evaluated in mixed cultures of bacterial assemblages from the Weddell Sea by Bjørnsen \& Kuparinen (1991).

For the microbial assemblages present in the western Bransfield Strait during the 1986-1987 austral summer, Karl et al. (1991) reported that ${ }^{3} \mathrm{H}$-thymidine appeared to have been extensively incorporated into macromolecules other than DNA; the total radioactivity incorporated into DNA as a percentage of total acid insoluble material ranged from $<10 \%$ at selected stations in December to $>50 \%$ later in the season. However, despite the fact that the 3 extraction procedures used in the present study must correspond to different fractions of the synthetized bacterial material, they yield relatively similar results.

Acknowledgements. This research was supported by the 'Institut Français pour la Recherche et la Technologie Polaire'

\section{LITERATURE CITED}

Azam F, Fenchel $T$, Field JG, Grey JS, Meyer-Reil LA, Thingstad $F$ (1983) The ecological role of water-column microbes in the sea. Mar Ecol Prog Ser 10:257-263

Bååth E (1994) Thymidine and leucine incorporation in soil bacteria with different cell size. Microb Ecol 27:267-278

Bell RT, Ahlgren GM, Ahlgren I (1983) Estimating bacterioplankton production by measuring ${ }^{3} \mathrm{H}$ thymidine incorporation in a eutrophic Swedish lake. Appl Environ Microbiol 45:1709-1721

Bjornsen PK, Kuparinen J (1991) Determination of bacterioplankton biomass, net production and growth efficiency in the Southern Ocean. Mar Ecol Prog Ser 71:185-194

Børsheim KY (1990) Bacterial biomass and production rates in the Gulf Stream front regions. Deep Sea Res 37: $1297-1309$

Bratbak G, Hedal M, Thingstad F, Riemann B, Haslund $O H$ (1992) Incorporation of viruses into the budget of microbial C-transfer. A first approach. Mar Ecol Prog Ser 83:273-280

Bratbak G, Thingstad F, Hedal M (1994) Viruses and the microbial loop. Microb Ecol 28:209-221

Chrzanowski TH, Simek K, Sada RH, Williams S (1993) Estimates of bacterial growth rate constants from thymidine incorporation and variable conversion factors. Microb Ecol 25: $121-130$

Coveney MF, Wetzel RG (1988) Experimental evaluation of conversion factors for the ${ }^{3} \mathrm{H}$ thymidine incorporation assay of bacterial secondary productivity. Appl Environ Microbiol 54:2018-2026

Delille D, Bouvy $M$ (1989) Bacterial responses to natural organic inputs in a marine subantarctic area. Hydrobiologia $182: 225-238$

Delille D, Bouvy M, Cahet G (1988) Short term variations of bacterio-plankton in Antarctic zone: Terre Adélie area. Microb Ecol 15:293-309

Delille D. Perret E (1989) Influence of temperature on the growth potential of southern polar bacteria. Microb Ecol 18:117-123

Ducklow HW (1994) Modeling the microbial food web. Microb Ecol 28:303-319

Ducklow HW, Kirchman DL, Quinby HL (1992) Bacterioplankton cell growth and macromolecular synthesis in seawater cultures during the North Atlantic spring phytoplankton bloom, May 1989. Microb Ecol 24:125-144 
Fuhrman JA, Azam F (1982) Thymidine incorporation as a measure of heterotrophic bacterioplankton in marine surface waters: evaluation and field results. Mar Biol 66: $109-120$

Hanson RB, Pope DH (1981) Bacterioplankton adaptation and growth in different in zones of the Southern Ocean. Antarct J US 16:130-132

Helmke E, Weyland H (1995) Bacteria in sea ice and underlying water of the eastern Weddell Sea in midwinter. Mar Ecol Prog Ser 117:269-287

Herbert RA, Tanner AC (1977) The isolation and some characteristics of photosynthetic bacteria (Chromatiaceae and Chlorobiaceae) from Antarctic manine sediments. J Appl Bacteriol 43:437-445

Hobbie JE, Daley RJ, Jasper S (1977) Use of Nuclepore filters for counting bacteria by fluorescence microscopy. Appl Environ Microbiol 33:1225-1228

Hoch MP, Kirchman DL (1993) Seasonal and inter-annual variability in bacterial production and biomass in a temperate estuary. Mar Ecol Prog Ser 98:283-295

Karl DM, Holm-Hansen O, Taylor GT, Tien G, Bird DF (1991) Microbial biomass and productivity in the western Bransfield Strait, Antarctica during the 1986-87 summer. Deep Sea Res 38:1029-1055

Kirchman DL (1992) Incorporation of thymidine and leucine in the subarctic Pacific: application to estimating bacterial production. Mar Ecol Prog Ser 82:301-309

Kirchman DL, Ducklow H (1993) Estimating conversion factors for the thymidine and leucine methods for measuring bacterial production. In: Kemp PF, Sherr BF, Sherr EB, Cole JJ (eds) Aquatic microbial ecology. Lewis Publ, Boca Raton, p 513-517

Kirchman DL, Ducklow H, Mitchell R (1982) Estimates of bacterial growth from changes in uptake rates and biomass. Appl Environ Microbiol 44:1296-1307

Kuosa H, Kivi K (1989) Bacteria and heterotrophic flagellates in the pelagic carbon cycle in the northern Baltic Sea. Mar Ecol Prog Ser 53:93-100

McMeekin TA, Franzmann PD (1988) Effect of temperature on the growth rates of halotolerant and halophilic bacteria isolated from Antarctic saline lakes. Polar Biol 8:281-285

Morita RY, Griffiths RP, Hayasaka SS (1977) Heterotrophic activity of microorganisms in Antarctic water. In: Llano GA (ed) Adaptation within Antarctic ecosystems. Gulf Publishing Co, Houston, p 99-113

Nedwell DB, Rutter MI (1994) Influence of temperature on growth rate and competition between two psychrotolerant

Responsible Subject Editor: T. F. Thingstad, Roskilde, Denmark
Antarctic bacteria: low temperature diminishes affinity for substrate uptake. Appl Environ Microbiol 60:1984-1992

Oppenheimer $\mathrm{CH}$, ZoBell CE (1952) The growth and viability of sixty-three species of marine bacteria as influenced by hydrostatic pressure. J Mar Res 11:10-18

Pace ML, Cole JJ (1994) Comparative and experimental approaches to top-down and bottom-up regulation of bacteria. Microb Ecol 28:181-193

Riemann B, Bell RT (1990) Advances in estilating bacterial biomass and growth in aquatic systems. Arch Hydrobiol 118:385-422

Rivkin RB, Anderson MR, Lajzerowicz C (1996) Microbial processes in cold oceans. I. Relationship between temperature and bacterial growth rate. Aquat Microb Ecol 10:243-254

Scavia D, Laird GA (1987) Bacterioplankton in Lake Michigan: dynamics, controls, and significance to carbon flux. Limnol Oceanogr 32:1017-1033

Shiah F, Ducklow HW (1994) Temperature regulation of heterotrophic bacterioplankton abundance, production and specific growth rate in Chesapeake Bay. Limnol Oceanogr 39:1243-1258

Shiah F, Ducklow HW (1995) Regulation of bacterial abundance and production by substrate supply and bacterivory: a mesocosm study. Microb Ecol 30:239-255

Simon M, Azam F (1989) Protein content and protein synthesis rates of planktonic marine bacteria. Mar Ecol Prog Ser 51:201-213

Smits JD, Riemann B (1988) Calculation of cell production from ${ }^{3} \mathrm{H}$ thymidine incorporation with freshwater bacteria. Appl Environ Microbiol 54:2213-2219

Steward GF, Smith DC, Azam F (1996) Abundance and production of bacteria and viruses in the Bering and Chukchi Seas. Mar Ecol Prog Ser 131:287-300

Straka RP, Stokes JL (1960) Psychrophilic bacteria from Antarctica. J Bacteriol 80:622-625

Weinbauer MG, Peduzzi P (1995) Significance of viruses versus heterotrophic nanoflagellates for controlling bacterial abundance in the northern Adriatic Sea. J Plankton Res 17:1851-1856

Wicks RJ, Robarts RD (1987) The extraction and purification of DNA labelled with $\left[{ }^{3} \mathrm{H}\right.$-metyl] thymidine in aquatic bacterial production studies. J Plankton Res 9: 1159-1166

Wicks RJ, Robarts RD (1988) Ethanol extraction requirement for purification of protein labeled with ${ }^{3} \mathrm{H}$ leucine in aquatic bacterial production studies. Appl Environ Microbiol 54:3191-3193

Manuscript received: October 4, 1996

Revised version accepted: March 19, 1997 